\title{
UNSUR BERAHI DALAM PANTUN KASIH SAYANG MELAYU BRUNEI DI SABAH ${ }^{1}$
}

\section{(The Elements of Lust and Affection in the Love Pantuns of Brunei Malays in Sabah)}

\author{
Low Kok On \\ lowkokon@ums.edu.my \\ Unit Penyelidikan Warisan Borneo, \\ Universiti Malaysia Sabah.
}

\begin{abstract}
Abstrak
Suku kaum Melayu Brunei telah menetap di sepanjang persisiran pantai barat Sabah sejak dari zaman awal Kesultanan Melayu Brunei lagi. Seperti suku kaum Melayu lain di Nusantara, berpantun ialah sebahagian daripada budaya mereka yang istimewa sejak dari dahulu hinggalah sekarang. Dalam kerja lapangan yang telah dijalankan di beberapa buah kampung Melayu Brunei di sekitar pantai barat Sabah, sejumlah pantun yang bertemakan cinta dan kasih sayang telah dirakamkan, ditranskripsi dan didokumentasi. Pantun kasih sayang yang terkumpul ini, antaranya menonjolkan unsur-unsur rasa rindu, jatuh hati, naik berahi dan hajat di hati untuk merisik dan meminang. Selain mendokumentasi sejumlah pantun yang bertemakan cinta dan kasih sayang, tumpuan kupasan dalam makalah ini adalah terhadap unsur "berahi" yang terbayang dalam pantun kasih sayang orang Melayu Brunei. Selain itu, perbandingan terhadap pantun cinta Melayu Brunei di Sabah dengan pantun cinta Melayu dan Tionghoa Peranakan terpilih juga akan dilakukan. Menerusi kupasan sedemikian, keistimewaan perasaan cinta dan berahi dalam budaya suku kaum Melayu Brunei di Sabah akan tertonjol kepada pembaca.
\end{abstract}

Kata kunci: Melayu Brunei, pantun cinta, kasih sayang, unsur berahi. Abstract
The Brunei Malay ethnic group settled all along the western shores of Sabah
since the early part of the formation of the Brunei Malay Sultanate. As is the
case with other Malay ethnic groups in Nusantara, reciting the pantun is 
part of their unique culture since the bygone days until the present time. In a field study conducted in several Malay Brunei kampongs along the western shores of Sabah, a number of pantuns with the themes of love and affection were recorded, transcribed and documented. These love pantuns that have been collected, among other things highlight the elements of yearning, falling in love, feeling amorous and wanting to seek a person's hand in marriage. Apart from documenting some pantuns with the themes of love and affection, the focus of this article is on the element of lust which is reflected in these pantuns of love of the Brunei Malays. In addition, a comparison will be made between these love pantuns and selected Malay and Straits-born Chinese pantuns. By making this analysis, the uniqueness of the elements of lust and affection in Brunei Malay pantuns will be unravelled.

Keywords: Brunei Malay, loved pantun, affection, elements of lust

\section{PENGENALAN}

Berdasarkan catatan sejarah, orang Melayu Brunei yang berasal dari negara Brunei Darussalam telah berada di Sabah sejak kurun yang ke-16 Masihi (Muzium Sabah, 1992:7). Di Sabah, kebanyakan mereka menetap di daerah Papar, Beaufort dan Sipitang (Peta Daerah Sabah). Menurut catatan Muzium Sabah (1992:7), Sabah ialah sebahagian daripada empayar Kesultanan Melayu Brunei sebelum Sabah ditadbir oleh Syarikat Berpiagam (British) Borneo Utara. Oleh hal yang demikian, banyak orang Melayu Brunei telah datang berniaga dan bercucuk tanam di sekitar pantai barat Sabah. Lamakelamaan, sesetengah daripada mereka memilih untuk menetap di sekitar Sabah sehingga hari ini.

Dalam Laporan Banci Penduduk Mengikut Daerah Pentadbiran dan Kumpulan Etnik Sabah 2010 (Jabatan Perangkaan Malaysia, 2010) tercatat bahawa terdapat sebanyak 545700 orang Kadazandusun, 398100 orang Bajau, 362700 orang Melayu dan 97300 orang Murut di Sabah. Orang Melayu Brunei, orang Kedayan dan beberapa suku Melayu lain dikelompokkan ke dalam kumpulan orang Melayu dalam perangkaan ini. Budaya, kepercayaan dan bahasa orang Melayu Brunei di Sabah tidak jauh berbeza daripada budaya, kepercayaan dan bahasa orang Melayu Brunei di Negara Brunei Darussalam. Suku kaum Melayu Brunei di Sabah beragama Islam dan menuturkan bahasa Melayu Brunei seperti juga dengan orang Melayu Brunei di Negara Brunei Darussalam. 


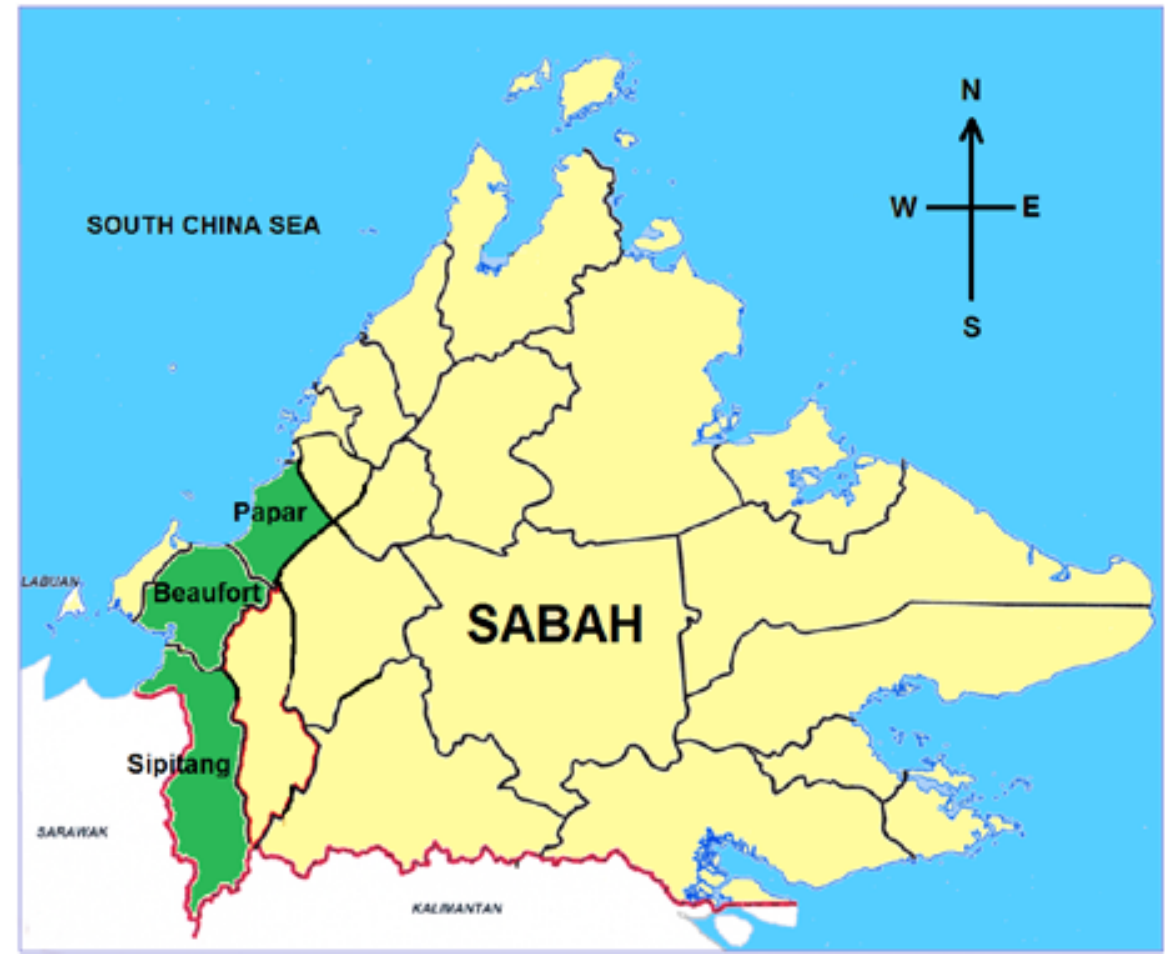

Rajah 1 Daerah Sabah: Daerah Papar, Beaufort dan Sipitang (Hijau). (Ihsan daripada Normadiah Nassir)

Orang Kaya-kaya Haji Maidin (pemberi maklumat) ketika ditemu bual memberitahu bahawa disebabkan sudah lama menetap di Sabah, pertuturan orang Melayu Brunei di sini sudah bercampur dengan pertuturan Melayu loghat Sabah. Berbanding dengan orang Melayu di Brunei, percakapan orang Melayu Brunei di Sabah lebih laju sedikit. Sama seperti orang Melayu di Brunei Darussalam, berpantun merupakan salah satu budaya turun-temurun orang Melayu Brunei di Sabah juga. Dalam kerja lapangan yang dijalankan di beberapa buah kampung Melayu Brunei yang terletak di daerah Papar dan daerah Beaufort, sejumlah pantun yang bertemakan kasih sayang telah dikumpul. Pantun kasih sayang yang terkumpul ini antaranya menonjolkan rasa berahi, rindu, jatuh hati dan hajat di hati untuk merisik dan meminang. Dalam tulisan ini, hal-hal yang berkait dengan perasaan berahi, yang terakam dalam pantun kasih sayang Melayu Brunei akan diberikan tumpuan semasa perbincangan. Selain menganalisis pantun Melayu Brunei yang bertemakan 
berahi, perbandingan antara pantun berunsurkan berahi orang Melayu Brunei di Sabah dengan pantun cinta Melayu dan Tionghoa Peranakan terpilih juga akan dilakukan. Dengan berbuat demikian, diharapkan hal-hal yang berhubung rapat dengan perasaan berahi dalam pantun suku kaum Melayu Brunei di Sabah dapat ditonjolkan kepada umum.

\title{
PANTUN KASIH SAYANG DALAM BUDAYA MELAYU
}

Selain memainkan fungsi yang signifikan dalam budaya Melayu sejak dari dahulu hingga sekarang, pantun turut menonjolkan unsur kearifan tempatan orang Melayu. Sehubungan dengan itu, Muhammad Haji Salleh (2009: xix) semasa membicarakan puisi tradisional Melayu mencatatkan:

\begin{abstract}
Melayu Poetry is the playground of the Malay local genius. While the early incantatory were magical in their connotations and practical uses, the pantuns, the four-line verse, is the most important. No other verse form has been so intertwined with the life of the society, as it has been-it is used by mother for lullabies, by children at play, by youths for courting, by adults for proverbs and traditional customary laws.
\end{abstract}

Atas sebab terdapat terlalu banyak pantun dalam budaya Melayu (dalam Kurik Kundi Merah Saga: Kumpulan Pantun Lisan Melayu (2002) sebagai contoh yang mendokumentasikan sejumlah 5653 rangkap pantun); pengkategorian pantun menurut kategori yang tepat dan secara menyeluruh merupakan satu perkara yang sukar dilakukan. Beberapa percubaan untuk mengkategorikan pantun telah dilakukan oleh pengkaji awal Barat. Van Ophusyen sebagai contoh telah mengkategorikan pantun menurut peringkat umur, aktiviti kehidupan dan fungsi seperti yang berikut (Jadual 1).

Pengkategorian pantun awal yang dilakukan oleh Van Ophusyen pada sekitar 1920-an ini ternyata tidak menyeluruh dan berasaskan kriteria yang

Jadual 1 Kategori pantun Van Ophusyen.

\begin{tabular}{|l|l|l|}
\hline Bil. & Kategori & Catatan \\
\hline 1. & Pantun orang tua & to get acquainted, for courtship \\
\hline 2. & Pantun orang muda & for those who love each other \\
\hline 3. & Pantung dagang & for those who part from each other \\
\hline 4. & Pantun nasihat & of broken heart \\
\hline
\end{tabular}

(Sumber: Harun Mat Piah, 1989:161) 
tidak sama. Dari segi peringkat umur manusia, terdapat sejumlah pantun yang dikhaskan untuk kanak-kanak, namun pantun kanak-kanak tidak muncul dalam kategori yang dilakukan oleh Van Ophusyen. Dalam konteks ini, Mohamad Azmi (2010:125) menyatakan bahawa pengkategorian pantun dari sudut khalayak secara umumnya dapat dibahagikan kepada pantun kanak-kanak, pantun orang dewasa dan pantun orang tua. Dari segi aktiviti kehidupan orang Melayu pula, selain pantun yang bertemakan dagang, terdapat pantun yang bertemakan aktiviti lain yang tidak dikategorikan, seperti bertani, memburu dan belayar. Dalam empat kategori pantun di atas, pantun kasih sayang tergolong dalam kategori pantun orang muda, manakala pantun agama dan nasihat tergolong dalam kategori pantun orang tua. Sehubungan dengan itu, Harun (1989:162) berpendapat bahawa bukan semestinya orang muda sahaja yang menggunakan pantun kasih sayang atau cinta dan orang tua pula menggunakan pantun agama dan nasihat. Hampir semua aktiviti kesenian tradisional orang Melayu seperti bongai, lotah, rodat, dondang sayang dan banyak lagi melibatkan orang tua-tua dan hampir semua pantun yang dipungut daripada aktiviti ini didapati ialah pantun cinta, berahi dan kasih sayang (Harun, 1989:162).

Berasaskan maksud atau isi pantun, terdapat bermacam-macam jenis pantun dalam budaya Melayu. Antaranya termasuklah pantun yang bertemakan nasihat, sindiran, kasih sayang, adat resam, agama dan banyak lagi. Kembali kepada pantun kasih sayang, pantun orang muda yang dikategorikan oleh Van Ophusyen (1920) ${ }^{2}$ ini berpusat pada orang muda yang jatuh cinta (young man in love). Pantun dalam kategori ini dianggap sebagai pusat pada segala pantun (Daillie, 1990:65). Catatan Daillie (1990) seperti ini menunjukkan betapa signifikannya pantun yang bertemakan kasih sayang dalam kalangan orang Melayu. Harun (1989:167) melaporkan bahawa daripada 3000 rangkap pantun yang diperiksa tema dan isinya, didapati 60 peratus daripadanya berkait rapat dengan kehidupan bercinta antara pasangan kekasih. Mohamad Azmi (2010:126) semasa membicarakan topik simbolisme dalam pantun percintaan Melayu melaporkan bahawa pantun yang bertemakan cinta lebih banyak dicipta oleh orang Melayu daripada tema lain. Hal ini disebabkan sentuhan cinta merupakan pengalaman yang berbekas dalam jiwa pencipta pantun. Boleh dikatakan jiwa seseorang, tidak kira sama ada lelaki atau perempuan, banyak terusik dengan hal-hal percintaan dalam hidup masing-masing. Jika diamati, pantun kasih sayang turut membayangkan banyak sekali unsur percintaan. Antaranya termasuklah berkenalan, berahi, berkasih sayang, rindu, cemburu, kesetiaan cinta, perpisahan, janji dan banyak lagi. Dalam 
tulisan ini, tumpuan analisis adalah terhadap pantun percintaan orang Melayu Brunei di Sabah yang membayangkan unsur "berahi" sahaja. Sebelum analisis terhadap pantun kasih sayang orang Melayu Brunei dilakukan, ada baiknya perkataan cinta, kasih sayang dan unsur berahi dijelaskan terlebih dahulu.

\section{CINTA, KASIH SAYANG DAN BERAHI: SATU PENJELASAN}

Kata cinta, kasih sayang dan berahi mempunyai pelbagai maksud yang luas. Maksud ketiga-tiga kata, iaitu cinta, kasih sayang dan berahi yang dicatatkan dalam Kamus Dewan (2005) harus diteliti terlebih dahulu. Umumnya, kata "cinta" merujuk perasaan sayang kepada negara, orang tua, kebebasan, perasaan berahi (asyik, kasih, sayang) antara lelaki dan perempuan serta perasaan ingin akan sesuatu atau rindu (Kamus Dewan, 2005:280). Kata "kasih" diberikan maksud perasaan sayang terhadap seseorang atau sesuatu, cinta serta berasa sayang akan sesuatu atau berasa cinta akan sesuatu (Kamus Dewan, 2005:682). Kata "sayang" diberikan erti sebagai mengasihi, mencintai, berasa belas akan sesuatu, kasih, cinta, kekasih, jantung hati dan terasa kesal (Kamus Dewan, 2005:1400). Seterusnya, kata berahi pula diertikan tiga makna, yakni (i) kasih (cinta) yang amat sangat; (ii) rasa suka akan seseorang (dengan bernafsu); dan (iii) sangat suka (Kamus Dewan, 2005:166). Berdasarkan maksud yang diberikan terhadap kata cinta, kasih, sayang dan berahi dalam Kamus Dewan (2005), jelas bahawa ketiga-tiga kata ini berkait rapat antara satu sama lain dan mempunyai perbezaan dari segi konteks penggunaannya.

Pantun yang bertemakan berahi tergolong sebagai pantun kasih sayang jua. Sehubungan pantun kasih sayang, Harun (1989:167) mencatatkan bahawa seluruh pantun kasih sayang membayangkan perasaan, harapan, pengalaman dan pergolakan jiwa antara lelaki dengan perempuan yang sedang bercinta. Jika diperluas maksudnya, mana-mana pantun yang isinya menyatakan perasaan suka antara lelaki dan perempuan, jatuh hati, berahi, rindu dan banyak lagi tergolong sebagai pantun kasih sayang. Selain itu, perasaan benci kerana cinta tidak kesampaian, cemburu atas sebab adanya cinta, menanggung seksa kerana cinta turut tergolong dalam pantun kasih sayang. Dengan kata lain, pantun cinta atau kasih sayang yang dimaksudkan ini membayangkan cetusan emosi yang berkait dengan perasaan cinta, asyik, berahi, kasih sayang, rindu, benci, cemburu dan banyak lagi perasaan yang bersabit dengan cinta seseorang. 
Berbalik kepada kata "berahi”" secara khusus, dalam hikayat Melayu lama, ditemui gambaran yang mencerminkan aspek psikologi terhadap konsep "berahi" seperti yang berikut:

"Maka terlalu "berahi" hatinya (Tuan Puteri) melihat burung itu, kerana rupanya terlalu indah."

"Adapun yang di atas itu beberapa ceritera yang amat indah-indah memberi "berahilah" akan segala yang membaca dia atau yang mendengarkan dia."

(Braginsky, 1998:194)

Berdasarkan petikan di atas, jelas bahawa kata berahi merujuk konsep "terpikat" dan "tertarik" akan sesuatu kerana unsur keindahan atau kecantikannya. Dalam Hikayat Inderaputra sebagai contoh, ditemui gambaran putera raja yang berahi terhadap Candera Lela Nur Lela seperti yang berikut:

Maka tuan puteri pun tersenyumlah seraya memandang ke bawah mahligai itu. Maka anak raja itu pun memandang ke atas. Maka sama terpandang muka tuan Puteri Candera Lela Nur Lela dengan anak raja itu. Maka anak raja itu pun seperti lenyaplah rasanya ia dalam laut "berahi" itu, sebab terlalu elok rupanya tuan puteri itu ...

(Braginsky, 1998:195)

Yang jelas bagi kita adalah dalam hikayat klasik Melayu, penggunaan kata yang merujuk "berahi" telah menonjolkan konsep keindahan orang Melayu pada masa silam. Konsep keindahan menurut Braginsky (1998: 198) akan merangsang berahi dan cinta yang bergelora seperti yang dinyatakan dalam petikan berikut:

Maka segala laki-laki dan perempuan jikalau menengar hikayat yang baik ceriteranya menjadi rindu dendamlah hatinya dan jadi "berahi" hatinya pada hikayat itu. Adalah setengahnya yang "berahi" kepada yang membaca istimewa yang baik suaranya dan lagunya, maka bertambahlah berahi hati yang menengar itu. Jangankan perempuan tiada menjadi gemirang hatinya, sedangkan laki-laki kebanyakan menjadi berdebar hatinya menengar ceritera hikayat itu berpatutan dengan suara yang membaca. Maka setengahnya adalah orang yang membaca sendiri menengar suaranya sendiri dan serta memikirkan ceriteranya hikayat amat indah karangannya, maka iapun terkadang jadi rindu dan dendam dan "berahi" dengan suaranya sendiri seraya di dalam hatinya, maka jadilah seperti orang yang gila sekalian manusia yang tersebut itu". 
Berahi turut membawa maksud jatuh hati atau jatuh cinta. Dalam Sejarah Melayu (Shellabear, 1978:77) sebagai contoh, tercatat kisah pemerintah Samudera yang membuat lawatan ke Pasai walaupun menteri baginda telah menasihatkan baginda supaya jangan pergi ke situ kerana saudara lelakinya tidak ada di sana. Baginda kemudian telah "jatuh berahi” kepada salah seorang inang di istana saudara lelaki baginda dan melarikannya. Tidak lama kemudian baginda menginsafi yang baginda telah melakukan kesalahan. $\mathrm{T}$. Iskandar (1987:2-6) dalam tulisannya memberikan catatan berikut tentang Hamzah Fansuri, yang perkataan "berahi akan" ternyata membawa maksud "cinta akan".

Syair-syair Hamzah Fansuri yang terkenal antaranya seperti Syair Si Burung Pingai, Syair Si Burung Pungguk, Syair Sidang Fakir, Syair Dagang dan Syair Perahu. Seluruh karya Hamzah ini merupakan ajaran Tarekat Wujudiyah. Syair-syairnya menunjukan bahawa Hamzah menguasai puisi Parsi yang bersifat tasawuf dan yang memupuk "berahi akan" Allah. Beliau ialah penyajak Melayu pertama yang memakai syair dalam tulisan agama.

Demikianlah penjelasan tentang kata berahi yang ditemui dalam karya klasik Melayu. Maksud berahi sedemikian berkait rapat dengan perbicaraan pantun kasih sayang yang bakal dihuraikan dalam tulisan ini. Atas sebab pantun kasih sayang adalah begitu luas dan banyak jumlahnya, maka tumpuan perbincangan tulisan ini adalah terhadap pantun yang isinya merujuk unsur berahi, yang diertikan sebagai pantun yang menonjolkan perasaan kasih yang amat sangat, rasa suka akan seseorang serta perasaan suka yang membawa nafsu antara si lelaki dengan si perempuan.

\section{PANTUN KASIH SAYANG ORANG MELAYU BRUNEI}

Salah satu soalan yang timbul apabila membicarakan pantun kasih sayang adalah dari mana hendak memulakannya? Jika diamati, dalam dunia percintaan, boleh ditemui beberapa peringkat menurut kronologi. Terdapat pengkaji seperti Daillie (1990:65) yang membahagikan pantun kasih sayang antara lelaki dengan perempuan menurut empat peringkat cinta sebagaimana yang ditunjukkan dalam Jadual 2.

Pengkategorian pantun yang bersabit dengan orang muda jatuh cinta dalam Jadual 2 kelihatan agak munasabah kerana berasaskan peringkat cinta dan kasih sayang dalam kalangan orang yang bercinta. Jika dilihat kronologi peringkat cinta antara lelaki dengan perempuan, pembahagian 
Jadual 2 Pantun cinta menurut peringkat.

\begin{tabular}{|l|l|l|}
\hline Bil. & Kategori & Catatan \\
\hline 1. & Pantun berkenalan & to get acquainted, for courtship \\
\hline 2. & Pantun berkasih-kasihan & for those who love each other \\
\hline 3. & Pantung berceraian & for those who part from each other \\
\hline 4. & Pantun berhiba hati & of broken heart \\
\hline
\end{tabular}

berdasarkan faktor umur seperti yang dilakukan oleh pengkaji sebelum ini dianggap kurang tepat. Perasaan cinta antara lelaki dengan perempuan, sebagai contoh, tidak semestinya terhad kepada muda-mudi sahaja. Umum mengetahui bahawa perasaan cinta antara lelaki dengan perempuan boleh bermula seawal lingkungan umur sebelas atau dua belas tahun. Lebih-lebih lagi terdapat orang tua yang mungkin ada perasaan cinta atau jatuh cinta, tidak kira sama ada lelaki atau pun perempuan.

Secara logiknya, cinta bermula apabila seseorang lelaki atau perempuan mula tertarik, terpikat atau suka akan satu sama lain, tidak kira dalam kalangan orang muda, orang dewasa atau pun orang tua. Dengan kata lain, perasaan suka akan seseorang antara lelaki dan perempuan berhubung rapat dengan kata "berahi”" (Kamus Dewan, 2005:166). Situasi ini mungkin boleh berlaku pada pertemuan buat kali pertama atau ketika berkenalan. Dalam konteks ini, orang Melayu Brunei menggambarkan perasaan berahi dengan indah melalui pantun Melayu Brunei berikut:

Jadual 3 Pantun Melayu Brunei.

\begin{tabular}{|l|l|}
\hline Pantun Melayu Brunei & Penjelasan/Catatan \\
\hline $\begin{array}{c}\text { Anuman gunung sakaki, } \\
\text { Pasir menjungkar alam manari; } \\
\text { Datang minuman dari Dang Siti, } \\
\text { Balum tarminum rasa barahi. }\end{array}$ & "Anuman" merujuk Hanuman, iaitu watak \\
dalam mitos Hindu. \\
"Gunung sakaki" bermaksud gunung \\
yang rendah. \\
"Pasir menjungkar" bermaksud pasir di \\
pantai yang memanjang ke hadapan. \\
\\
Dalam pertuturan orang Melayu Brunei \\
di Sabah, sekaki disebut sebagai sakaki, \\
menari disebut sebagai manari, belum \\
disebut sebagai balum dan terminum \\
disebut sebagai tarminum.
\end{tabular}


Pantun dalam Jadual 3 menggambarkan perasaan seorang lelaki yang berahi akan seorang perempuan. Terdapat banyak kemungkinan situasi berahi dalam pantun di atas akan berlaku dalam konteks kehidupan seharihari orang Melayu Brunei. Hal ini mungkin berlaku ketika seorang lelaki berkunjung ke rumah si perempuan. Ketika si perempuan membawa minuman untuk tetamu keluarganya, dan si tetamu lelaki jatuh hati kepadanya secara tiba-tiba. Pantun ini turut membayangkan tarikan yang ada pada seorang perempuan yang menyebabkan seorang lelaki berahi terhadapnya. Pantun yang menonjolkan unsur berahi turut ditemui dalam budaya orang Melayu seperti yang terbayang dalam pantun di bawah.

\author{
Belayar masuk Kuala Kedah, \\ Patah tiang timpa kemudi; \\ Sekuntum bunga terlalu indah, \\ Sekalian kumbang asyik berahi
}

(Kumpulan Pantun Melayu, 1983:1754)

Pantun yang bertemakan berahi di atas membayangkan seorang perempuan yang cantik akan menyebabkan banyak lelaki berahi terhadapnya. Kecantikan perempuan yang menyebabkan timbulnya perasaan berahi seseorang lelaki terhadapnya boleh dianggap sebagai sesuatu kejadian lumrah yang berlaku dalam diri manusia. Dalam pantun Melayu Brunei, "Dang Siti” ialah lambang perempuan yang cantik seperti juga "sekuntum bunga" dalam pantun Melayu. Orang Melayu gemar mencipta pantun yang menggunakan kumbang sebagai lambang lelaki. Yang berikut ialah sebuah lagi pantun percintaan Melayu yang dimaksudkan:

Tebang gelam tebang kenanga,

Kenangan tumbang menimpa gedung;

Kumbang mengidam nak seri bunga,

Bunga kembang di puncak gunung.

(Rahman Shaari, 1993:68)

Frasa "Kumbang mengidam nak seri bunga" bagi pantun di atas sekali lagi menonjolkan rasa berahi seorang lelaki terhadap seorang perempuan. Seperkara yang ingin dijelaskan di sini adalah dalam kedua-dua pantun berahi di atas, kumbang tidak semestinya melambangkan lelaki yang merosakkan kesucian perempuan. Umum beranggapan kumbang diberikan lambang lelaki yang jahat seperti yang terbayang dalam sekadar dua contoh pantun di bawah. 
Zaman berperang Raja Berma,

Peluru sampai di pucuk kayu;

Seekor kumbang menyeri bunga,

Kumbang terbang bunga pun layu.

Nasi dingin bersayur mumbang,

Sayur dimasak dalam belangga;

Kami tak ingin melihat kumbang,

Kalau kumbang merosak bunga.

(Mohamad Azmi, 2010:131)

Pantun yang bertemakan rasa berahi atau suka akan seseorang boleh dikenal pasti berdasarkan beberapa situasi lain, selain pantun yang menggunakan kata berahi secara terus terang. Perhatikan pantun Melayu berikut untuk perbincangan seterusnya.

Jalan-jalan sepanjang jalan,

Singgah-menyinggah di pagar orang;

Pura-pura mencari ayam,

Ekor mata di anak orang.

(Daillie, 1990:56)

Dalam pantun ini, perbuatan seorang lelaki yang berpura-pura mencari ayam, padahal niatnya untuk melihat anak perempuan orang lain ternyata menggambarkan perasaan berahi yang ada pada seorang lelaki terhadap seorang perempuan. Jika diteliti, pantun yang bertemakan berahi tidak terhad kepada pencipta pantun Melayu sahaja. Orang Tionghua Peranakan di Indonesia, sebagai contohnya, turut menghasilkan pantun yang membayangkan perasaan berahi ini dengan menarik seperti yang terdapat dalam pantun Tionghua Peranakan seperti dalam Jadual 4.

Jadual 4 Pantun Tionghua Peranakan Indonesia.

\begin{tabular}{|c|c|}
\hline Pantun Peranakan Tionghua Indonesia & Terjemahan \\
\hline $\begin{array}{l}\text { Di Soerabaja besar moearanja, } \\
\text { Pisang setandan baroe dipotong; } \\
\text { Baroe saja denger soewaranja, } \\
\text { Rasanja badan mati sepotong. } \\
\text { (L., 1922:33) }\end{array}$ & $\begin{array}{l}\text { Di Surabaya besar muaranya, } \\
\text { Pisang setandan baru dipotong; } \\
\text { Baru saya dengar suaranya, } \\
\text { Rasanya badan mati sepotong. }\end{array}$ \\
\hline
\end{tabular}


Jika dibandingkan, maksud frasa pantun Tionghua Peranakan "Baru saya dengar suaranya, Rasanya badan mati sepotong" agak mirip kepada maksud pantun Melayu Brunei "Datang minuman dari Dang Siti, Belum terminum rasa berahi". Kedua-dua pantun ini menyatakan perasaan berahi yang merujuk perasaan menaruh kasih yang amat sangat bagi seorang lelaki terhadap seorang perempuan. Perasaan berahi sedemikian dilihat lebih kepada situasi jatuh cinta seseorang daripada berahi kerana nafsu semata-mata. Dalam kerja lapangan yang dilakukan, pantun berahi yang sedemikian banyak dihasilkan oleh orang Melayu Brunei. Beberapa rangkap lagi pantun Melayu Brunei (PMB) berikut menonjolkan tema berahi yang dimaksudkan ini:

Jadual 5 Pantun Tionghua Peranakan Indonesia.

\begin{tabular}{|c|c|}
\hline PMB 1 & Penjelasan \\
\hline $\begin{array}{l}\text { Bedakku bedak kemboja, (1) } \\
\text { Kusandarkan di matahari; } \\
\text { Bedakku bukan sebentar muda, (2) } \\
\text { Barang mamandang gila berahi. }\end{array}$ & $\begin{array}{l}\text { (1) Bedak tradisional yang diperbuat } \\
\text { daripada beras. } \\
\text { (2) Bedak ini apabila disapukan di } \\
\text { muka akan membuat seseorang gadis } \\
\text { kelihatan cantik. }\end{array}$ \\
\hline PMB 2 & Penjelasan \\
\hline $\begin{array}{l}\text { Isap sigup tembakau Cina,(1) } \\
\text { Ada asap berbunga-bunga; } \\
\text { Bolehkah saya tumpang bertanya, } \\
\text { Si gadis itu siapa yang punya? }\end{array}$ & $\begin{array}{l}\text { (1) Sigup ialah kata tempatan Sabah } \\
\text { yang merujuk rokok yang diperbuat } \\
\text { daripada daun kirai. }\end{array}$ \\
\hline PMB 3 & Penjelasan \\
\hline $\begin{array}{l}\text { Naik kapal tengah lautan, } \\
\text { Dari Embun ke Surabaya; } \\
\text { Adinda manis sudah kelihatan, } \\
\text { Terbayang-bayang di bulu mata. }\end{array}$ & - \\
\hline PMB 4 & Penjelasan \\
\hline $\begin{array}{l}\text { Sudah lama inda ke Paris, (1) } \\
\text { Banyak rumah berbaris-baris; } \\
\text { Relaku mati di hujung keris, } \\
\text { Asalkan dapat si hitam manis. }\end{array}$ & (1) Inda bererti tidak. \\
\hline
\end{tabular}




\begin{tabular}{|l|l|}
\hline PMB 5 & Penjelasan \\
\hline $\begin{array}{l}\text { Kalau bukan padi di rumah, } \\
\text { Indalah aku datang ke mari; }\end{array}$ & (1) Indalah bererti tidaklah. \\
Kalau bukan pasal Si Limah, \\
$\quad$ Indalah aku datang ke mari.
\end{tabular}

Kelima-lima rangkap pantun Melayu Brunei (PMB) di atas membayangkan tema berahi belaka. Kata berahi dalam konteks perbincangan kelima-lima rangkap PMB yang berikut merujuk "perasaan suka akan", "terpikat" atau "tertarik" kepada seks lawan. Dalam kelima-lima rangkap PMB di atas, perasaan berahi sedemikian menjurus kepada si lelaki yang mempunyai "perasaan suka akan", "terpikat" atau "jatuh cinta" kepada si perempuan belaka.

Menurut informan yang ditemu bual, PMB 1 membayangkan rasa berahi yang ada pada seseorang lelaki terhadap seorang perempuan yang kelihatan cantik setelah dia menghiasi diri dengan bedak tradisional yang diperbuat daripada beras. Apabila seorang gadis kelihatan cantik, maka banyaklah lelaki yang akan berahi terhadapnya. Menurut informan lagi, lelaki yang berahi biasanya akan dalam keadaan siang terbayang-bayang dan malam pula akan termimpi-mimpi gadis yang disukainya. Demikianlah istimewanya perasaan berahi yang ada pada seorang lelaki terhadap seorang gadis yang terakam dalam pantun Melayu Brunei. Dalam Kurik Kundi Merah Saga (2002:673), ditemui sebuah pantun Melayu dari Sabah yang turut menonjolkan tema berahi seperti yang berikut:

\section{Bukan bukit saja meruntuh, Bamban serai meruntuh juga; \\ Bukan penyakit saja membunuh, \\ Gila berahi membunuh juga.}

Sebagai perbandingan, kedua-dua pencipta pantun ini menggunakan kata "gila berahi" untuk menyatakan betapa kuatnya kuasa yang ada pada berahi. Jika PMB 1 membayangkan betapa kuatnya kuasa yang ada pada seorang gadis cantik hingga menyebabkan seorang lelaki "gila berahi" terhadapnya; pantun ini pula membayangkan seseorang yang "gila berahi" bagaikan orang yang menghidap penyakit. Dengan kata lain, perasaan berahi adakalanya boleh menjadi sejenis penyakit yang menyeksakan jiwa seseorang. Hanya 
orang yang pernah mengalaminya dapat memahami betapa seriusnya penyakit psikologi "gila berahi” ini.

Seperti yang dinyatakan sebelum ini, pantun yang bertemakan berahi tidak semestinya menggunakan kata berahi. Orang Melayu Brunei di Sabah telah mencipta banyak lagi pantun yang bertemakan berahi tanpa penggunaan kata berahi secara nyata. PMB 2, sebagai contoh, telah membayangkan perasaan seorang pemuda yang suka akan seorang gadis, lalu bertanyakan kepada orang lain, si gadis itu kepunyaan siapa? Hal ini lumrah berlaku dalam masyarakat kita. PMB 2 boleh ditafsirkan dengan dua maksud yang berbeza. Pertama, lelaki yang jatuh hati kepada seorang gadis buat kali pertama bertemu dengannya ingin tahu sama ada si gadis berkenaan sudah berkahwin atau pun belum. Kedua, si lelaki yang jatuh hati itu ingin tahu siapakah ibu bapa si gadis itu? Pertanyaan sedemikian timbul semata-mata disebabkan perasaan berahi yang ada pada seorang lelaki terhadap seorang perempuan. Perhatikan serangkap pantun Melayu Sabah dalam Kurik Kundi Merah Saga (2002:685) di bawah, yang maksudnya mirip kepada PMB 2.

Hisap sigup tembakau Cina,

Keluar asap berbunga-bunga;

Jangan marah abang bertanya,

Bunga di taman siapa punya?

PMB 3 membayangkan perasaan berahi seorang lelaki terhadap seorang perempuan yang dipandangnya manis, justeru wajahnya sering terbayangbayang dalam benaknya. Penggunaan frasa "terbayang-bayang di bulu mata" didapati ada kaitan dengan wajah gadis manis yang dipandang oleh si lelaki yang berahi akannya. Dalam pantun ini, kita boleh katakan bahawa seorang lelaki berahi akan seorang gadis, maka gadis berkenaan kelihatan cantik dalam pandangannya. PMB 4 pula membayangkan betapa besarnya kuasa berahi hinggakan seorang lelaki rela mati asalkan dia dapat gadis hitam manis kesukaannya. Dalam pantun Melayu Brunei ini, gadis hitam manis melambangkan gadis Melayu Brunei yang cantik. Hal ini turut dibayangkan dalam sebuah lagi pantun Melayu Brunei yang dirakamkan di Brunei oleh Hashim (2003:198), iaitu seperti yang berikut:

Sayang tertirip tiram bergantung,

Limau manis bernila-nila;

Apa ditilik sebarang kampung,

Hitam manis memberi gila. 
Dalam pantun Melayu Brunei di atas, frasa "memberi gila" mirip kepada frasa "gila berahi" yang ditemui dalam PMB 1. Hal ini menunjukkan betapa besarnya tarikan yang ada pada seorang perempuan hinggakan dia membuat si lelaki "gila berahi". Berbalik kepada unsur kulit hitam yang melambangkan perempuan Melayu yang cantik turut ditemui dalam satu lagi pantun Melayu yang dirakamkan di Sabah seperti yang berikut.

\title{
Maritam berjunung kandis, \\ Karamuning lebat bunganya; \\ Tubuhlah hitam dipandang manis, \\ Putihlah kuning banyak gunanya.
}

(Kurik Kundi Merah Saga, 2002:701)

Pantun Melayu Sabah di atas menggunakan lambang warna hitam manis dan putih kuning. Mohamad Azmi (2010:135) dalam kajian perlambangan yang ditemui dalam pantun Melayu melaporkan bahawa dari segi warna, warna putih kuning dan hitam manis banyak dikesan penggunaannya dalam pantun percintaan Melayu. Warna putih kuning ialah lambang kecantikan perempuan (gadis) yang ingin dimiliki atau dirindui lelaki (jejaka). Menurut Mohamad Azmi (2010:136) lagi, putih kuning melambangkan gadis yang menawan hati lelaki. Pantun berikut dapat menjelaskan makna ini.

\author{
Sirih kuning pinangnya kelat, \\ Dimakan orang pagi hari; \\ Putih kuning gigi berkilat; \\ Hilang di mana abang nak cari?
}

Wilkinson dan Winstedt (1961:19) turut menghimpunkan sebuah pantun percintaan yang menonjolkan lambang putih kuning. Koleksi mereka ini menunjukkan betapa signifikannya kulit putih kuning ini yang memiliki kuasa menimbulkan rasa berahi dalam diri si lelaki. Pantun koleksi Wilkinson dan Winstedt (1961:19) berikut membayangkan maksud ini:

\author{
Sirih kuning pinangnya kelat, \\ Buluh perindu tidak berdahan; \\ Putih kuning marilah dekat, \\ Hati rindu tidak tertahan.
}

Jika diteliti, warna putih kuning yang dijadikan kulit si gadis yang menawan bukan hanya terhad kepada orang Melayu sahaja. Orang Tionghua 
MALAY LITERATURE VOLUME 29 NUMBER 12016

Jadual 6 Pantun Kasih Sayang Tionghua Peranakan Indonesia.

\begin{tabular}{|c|c|}
\hline $\begin{array}{l}\text { Pantun Peranakan Tionghua } \\
\text { Indonesia }\end{array}$ & Terjemahan \\
\hline $\begin{array}{l}\text { Siri sasoesoen satengah ikat, } \\
\text { Baek digantoeng di roemah Tjina, } \\
\text { Poeti koening dipandang tjakep, } \\
\text { Sayang sedikit ada jang poenja. } \\
\text { (Y.K.H, 1922:4) }\end{array}$ & $\begin{array}{l}\text { Sirih sesusun setengah ikat, } \\
\text { Baik digantung di rumah Cina; } \\
\text { Putih kuning dipandang cekap, } \\
\text { Sayang sedikit ada yang punya. }\end{array}$ \\
\hline
\end{tabular}

Peranakan di Indonesia turut memandang kulit putih kuning seseorang gadis menawan hati si jejaka. Pantun Tionghua Peranakan Indonesia dalam Jadual 6 membayangkan maksud ini:

Selain putih kuning, hitam manis turut melambangkan warna kulit si gadis Melayu Brunei. Selain itu, warna hitam manis juga melambangkan kuasa tarikan yang ada pada gadis Melayu yang lain. Tarikan hitam manis yang sedemikian dibayangkan dalam kedua-dua rangkap pantun Melayu di bawah:

Adas manis jintan di Jawa,

Rempahan anak burung merpati;

Hitam manis timbangan nyawa,

Adik terikat dalam hati.

(Mohamad Azmi, 2010:137)

Teritip tiram tergantung,

Limau manis banyak bijinya;

Pilih-pilih muda sekampung,

Hitam manis baik budinya.

(Mohamad Azmi, 2010:137)

Pantun yang kedua di atas ternyata membayangkan bahawa selain kulit hitam manis yang dapat menawan hati si lelaki, budi pekerti yang elok turut dapat menawan hati lelaki sekampung. Dalam konteks ini, kita boleh katakan kecantikan si gadis bersama-sama dengan budi pekertinya yang baik akan membuatkan si lelaki berahi terhadapnya.

Dalam khazanah pantun Melayu, terdapat sejenis lagi pantun bertemakan berahi yang menonjolkan unsur nafsu si lelaki terhadap si perempuan. Daillie 
(1990:4) menggunakan perkataan sensual (berunsur seks) bagi menerangkan hal ini seperti yang terbayang dalam contoh pantun berikut:

\author{
Tanam padi di bukit Jeram, \\ Tanam keduduk atas batu; \\ Macam mana hati tak geram, \\ Menengok tetek menolak baju?
}

Sayang sekali, kerja lapangan yang dilakukan setakat ini belum dibekalkan oleh mana-mana pemberi maklumat pantun berunsurkan berahi seks yang dimaksudkan ini. Namun hal ini tidak bermakna dalam kalangan orang Melayu Brunei tidak diciptanya pantun unsur berahi yang sedemikian rupa. Yang berikut diturunkan satu contoh pantun berunsurkan berahi seks dari Sabah yang ditemui dalam antologi Kurik Kundi Merah Saga (2002:715):

Sayang-sayang buah kepayang,

Makan isi kulit melayang;

Kalau terpandang aurat Si Dayang,

Punggung bergegar jantung bergoyang.

Jika diamati, pantun-pantun berunsurkan berahi dalam kalangan Melayu Brunei, Melayu dan Tionghua Peranakan mempunyai banyak persamaan yang agak ketara. Umumnya, boleh dikatakan ketiga-tiga golongan ini mempunyai persamaan dari segi bahasa, tempat tinggal dan budaya. Orang Melayu Brunei dan orang Melayu lain di Nusantara tergolong sebagai satu rumpun yang sama. Buat masa ini, aspek bahasa, gaya hidup, budaya dan pegangan agama mereka adalah hampir sama antara satu sama lain. Atas sebab ini, tidak hairanlah mengapa pantun berunsurkan berahi yang dihasilkan oleh mereka mempunyai banyak persamaan, terutamanya dari segi bahasa, lambang dan perasaan yang ditonjolkan dalam pantun mereka. Bagi golongan Tionghua Peranakan di Indonesia pula, mereka juga menuturkan bahasa Melayu dan mengamalkan budaya campuran Melayu-Cina sejak dari dahulu lagi. Banyak pendapat yang berbeza telah dikemukakan oleh sejarawan tentang asal usul masyarakat Tionghua Peranakan di Nusantara. Perbalahan pendapat dalam kalangan sejarawan tentang asal usul golongan Tionghua Peranakan tidak akan dibincangkan di sini.

Greif(1988:1), iaitu salah seorang pengkaji golongan Tionghua Peranakan mencatatkan bahawa semasa penjajah Belanda dalam usahanya secara peringkat demi peringkat memperluas kekuasaan mereka di Kepulauan Indonesia 
pada kurun yang ke-16, banyak lelaki Cina dari selatan China, yang cuba mengelakkan masalah politik dalam pemerintahan Manchu telah melarikan diri dan menetap di Indonesia. Kemudian, kumpulan imigran Cina awal ini, yang terdiri daripada kaum lelaki telah berkahwin dengan wanita tempatan di Indonesia (Grief, 1988:1 dan Salmon, 1984:1). Lama-kelamaan, mereka telah membentuk satu komuniti baharu yang dikenali sebagai "Peranakan". Grief (1988:2) seterusnya melaporkan:

\begin{abstract}
Previous to the 1860s, the numbers of Chinese were relatively small, only some 250,000 and largely of Peranakan stock. Throughout the previous three hundred years, new arrivals from China, exclusively male, continued spasmodically, and they too were absorbed into the Peranakan communities, where race mixing took place ...
\end{abstract}

Seperkara yang menarik ialah golongan Tionghua Peranakan Indonesia didapati telah menerbitkan banyak pantun dan syair dalam bentuk antologi sejak dari akhir kurun ke-19 lagi. Sehubungan dengan itu, Salmon (1984:28) melaporkan bahawa antara tahun 1866 hingga 1910, dikenal pasti sebanyak 27 orang pengarang Tionghua Peranakan yang menerbitkan 40 buah antologi syair. Low (2003:174) mendapati golongan Tionghua Peranakan di Indonesia tidak membezakan syair dan pantun. Bagi mereka, kedua-dua genre ini puisi belaka. Dengan kata lain, dalam antologi yang menggunakan kata "syair' sebagai judul, yang diterbitkan oleh mereka seperti Boekoe Sair Tjinta Tjoema Boeat Satoe (Botauwlo, 1950) sebagai contohnya memuatkan campuran antara syair dan pantun (Low, 2003:174). Dengan kata lain, antologi syair yang dihasilkan oleh pengarang Tionghua Peranakan seperti yang dilaporkan oleh Salmon (1984: 28) sebenarnya terbentuk daripada campuran pantun dan syair.

Dari segi asal usul kemunculan pantun Tionghua Peranakan pula, Low dan Sim (2012:114) melaporkan:

Harun Mat Piah (1989) reports that in the early stages, the Chinese Peranakan used the pantun as they were initially exposed to pantun before they fell back on their knowledge of Chinese poems. In view of the close association between the culture and spoken language of the Chinese Peranakan and those of the Malays, it is understandable that the Chinese Peranakan in Indonesia and the Straits Settlements were fascinated with pantun, which played a prominent role in the daily lives of the Malays at that time. As such, there is no denying that in the early stages, the Chinese Peranakan learned the skills of composing pantun from contemporary Malays.This statement can be supported with 
reference to early pantun anthologies published by the Chinese Peranakan, one of which has to do with pantun found in an anthology entitled Pantun Karang-karangan published by Mohamad bin Moor Ta Kup as early as 1889.

Seterusnya, Low dan Sim (2012:114) menegaskan bahawa berasaskan pengaruh Melayu atas kemunculan pantun Tionghua Peranakan awal ini maka tidak hairanlah mengapa terdapat banyak persamaan dalam pantun Tionghua Peranakan dan pantun Melayu.

\section{KESIMPULAN}

Berasaskan perbincangan di atas, jelas bahawa unsur berahi amat signifikan dengan pantun kasih sayang Melayu Brunei. Dalam pembicaraan pantun kasih sayang, tulisan ini antaranya menonjolkan unsur berahi sama ada membawa makna "sangat suka akan" atau "rasa suka akan seseorang (dengan bernafsu)" mendapat tempat yang penting dalam kalangan pencipta pantun Melayu Brunei. Selain itu, unsur berahi turut memperoleh tempat yang istimewa dalam kalangan pencipta pantun Melayu serta pencipta pantun Tionghua Peranakan. Akhir sekali, tulisan ini telah membicarakan pelbagai pantun berunsur berahi yang dicipta oleh orang Melayu Brunei yang menetap di Sabah. Antaranya termasuklah pantun berunsurkan berahi yang menggunakan kata "berahi" secara terus terang dan sesetengah pantun berunsurkan berahi yang dinyatakan secara tersirat tanpa menggunakan kata berahi. Hal ini menunjukkan bahawa unsur berahi adalah antara unsur yang penting dalam dunia percintaan antara si lelaki dengan si perempuan dalam budaya orang Melayu Brunei.

\section{NOTA}

1. Sebahagian daripada makalah ini telah dibentangkan dalam Seminar Folklor Nusantara 2015 di Kangar, Perlis dari 12 - 13 Oktober 2015.

2. Kajian Van Ophuysen banyak dicatat dalam Pantun Melayu yang diterbitkan oleh Balai Pustaka buat kali pertamanya pada tahun 1920.

\section{PENGHARGAAN}

Penulis ingin merakamkan setinggi-tinggi terima kasih kepada Cik Shazwani binti Mahmad yang telah membantu penulis menjalankan kerja lapangan merakam pantun daripada pemberi maklumat Melayu Brunei di Papar dan Bongawan, Sabah antara Disember 2012 hingga awal 2013. 
MALAY LITERATURE VOLUME 29 NUMBER 12016

\section{Senarai Pemberi Maklumat Melayu Brunei}

\begin{tabular}{|c|l|c|l|}
\hline Bil. & \multicolumn{1}{|c|}{ Nama } & Umur & \multicolumn{1}{c|}{ Tempat } \\
\hline 1. & Duraman bin Maidin & 81 & Kampung Padang, Bongawa \\
\hline 2. & $\begin{array}{l}\text { Dayang Hajah Lipah binti } \\
\text { Awang Mahmin }\end{array}$ & 92 & Kampung Benoni Darat, Papar \\
\hline 3. & $\begin{array}{l}\text { Dayang Hajah Fatimah } \\
\text { binti Awang }\end{array}$ & 62 & Kampung Benoni Darat, Papar \\
\hline 4. & $\begin{array}{l}\text { Hajah Amas binti Ampuan } \\
\text { Salleh }\end{array}$ & 79 & Kampung Benoni, Papar \\
\hline 5. & $\begin{array}{l}\text { OKK Tuan Haji Maidin } \\
\text { bin Budin }\end{array}$ & $\begin{array}{c}\text { Tidak } \\
\text { diperoleh }\end{array}$ & Papar \\
\hline 6. & $\begin{array}{l}\text { Pangeran Haji Abdul } \\
\text { Rahman bin Pangeran Ali }\end{array}$ & $\begin{array}{c}\text { Tidak } \\
\text { diperoleh }\end{array}$ & Kampung Padang, Bongawan \\
\hline
\end{tabular}

\section{RUJUKAN}

Braginsky, V.I., 1998. Yang Indah, Berfaedah dan Kamal: Sejarah Sastera Melayu dalam Abad 7-9. Jakarta: INIS.

Daillie, F-R., 1990. Alam Pantun Melayu: Studies on the Malay Pantun. Kuala Lumpur: Dewan Bahasa dan Pustaka.

Greif, S.W., 1988. Indonesian of Chinese Origin: Assimilation and the Goal of One Nation, One People. New York: The World Professors Peace Academy.

Harun Mat Piah, 1989. Puisi Melayu Tradisional: Satu Perbicaraan Genre dan

Fungsi. Kuala Lumpur: Dewan Bahasa dan Pustaka.

Kamus Dewan, 2005. Kuala Lumpur: Dewan Bahasa dan Pustaka.

Kumpulan Pantun Melayu, 1983. Kuala Lumpur: Dewan Bahasa dan Pustaka.

Kurik Kundi Merah Saga: Kumpulan Pantun Lisan Melayu, 2002. Kuala Lumpur:

Dewan Bahasa dan Pustaka.

L., 1922. Pantoen Bagoes Atawa Sindir-Sindiran Boeat Orang Moeda. Batavia: Toko dan Drukkerij Lie Tek Long.

Laporan Banci Penduduk Mengikut Daerah Pentadbiran dan Kumpulan Etnik Sabah, 2010. Jabatan Perangkaan Malaysia Cawangan Sabah.

Low Kok On, "Syair Tionghua Peranakan Indonesia" dlm. SARI: Jurnal Alam dan Tamadun Melayu 21, hlm. 171-82, 2003

Low Kok On dan Sim Chee Cheang, "The Significance of Natural Phenomenon in the

Malay and Chinese Peranakan Pantun(s) Message Reflectors" dlm. Journal of Zhejiang University (Humanities and Social Sciences) 42:1, hlm. 100-26, 2012. 
Mohamad Azmi Ab. Rahman, 2010. "Simbolisme dalam Pantun Percintaan Melayu" dlm. Naratif Baru Sastera Melayu Tradisional. Kuala Lumpur: Dewan Bahasa dan Pustaka.

Muhammad Haji Salleh, 2009. An Introduction to the Malay Literature. Kuala Lumpur: Institute Terjemahan Negara Malaysia Berhad.

Muzium Sabah, 1992. Warisan Sabah: Pengenalan Ringkas Sejarah dan Warisan Sabah. Kota Kinabalu: Muzium Sabah.

Rahman Shaari, 1993. Memahami Gaya Bahasa. Kuala Lumpur: Dewan Bahasa dan Pustaka.

Salmon, C., 1981. Sastera Cina Peranakan dalam Bahasa Melayu. Jakarta: PN Balai Pustaka.

Shellabear, W.G. (ed.), 1978. Sejarah Melayu. Petaling Jaya: Penerbit Fajar Bakti.

T. Iskandar, 1987. "Hamzah Fansuri: Pengarang, Penyair, Ahli Tasawuf Abad Ketujuh Belas" dlm. Mohamad Daud Mohamad (peny.), Tokoh-tokoh Sastera Melayu Klasik. Kuala Lumpur: Dewan Bahasa dan Pustaka.

Wilkinson, R.J. dan Winstedt, R.O., 1961. Pantun Melayu. Singapura: Malaya Publishing House Ltd.

Wisntedt, R.O., 1960, A History of Classical Malay Literature. Kuala Lumpur: Oxford University Press.

Y.K.H., 1922. Sair dan Pantoen Nona Manis Boengah Seronih. Batavia: Toko dan Drukkerij Lie Tek Long. 